\title{
Evaluasi Kapasitas Struktur: Sistem Struktur Pelat dengan balok dan alternative struktur Flat Slab dengan Drop Panel
}

\author{
Indra Yuwono Basuki ${ }^{1}$, Indra Komara ${ }^{2}$ \\ ${ }^{1}$ Teknik sipil, Fakultas Teknik Sipil dan Lingkungan, Institut Teknologi Adhi Tama Surabaya \\ ${ }^{2}$ Teknik sipil, Fakultas Teknik Sipil dan Lingkungan, Institut Teknologi Adhi Tama Surabaya \\ Email: 1indra.yuwonobasuki@gmail.com
}

\begin{abstract}
Reinforced concrete of flat slabs structure is generally become popular in building construction system for cast-in-site method. This method is supported by concrete column without the use of beams or by thickening the area of the column. It provides several benefits in the construction i.e., ease of construction, architectural flexibility and reduce the services. In fact, its efficiency is hindered by its indigent performance under earthquake load. In this study, two types of favored flat slabs will be evaluated, use of column heads and use of drop panels, to increase shear strength of slabs with reducing the moment in the slab by concerning the clear or effective span. A four-story building, IAIN Madura library building, with $6 \mathrm{~m}$ and $7.2 \mathrm{~m}$ panel span will be remodelled numerically in static equivalent and response spectrum analysis. The proposed goal of this study is to assess the performance of flat slabs in order to source the effectiveness of building parameter follow with standard
\end{abstract}

Keywords: Flat slabs, beam, thickening, drop panel, effectiveness

\begin{abstract}
Abstrak
Struktur beton bertulang dengan flat slab umumnya menjadi populer di sistem konstruksi bangunan untuk metode cor di tempat. Metode ini didukung oleh kolom tanpa menggunakan balok atau dengan penebalan area kolom. Konsep ini memberikan beberapa manfaat dalam konstruksi yaitu, kemudahan dalam konstruksi, fleksibilitas arsitektur dan mengurangi item pekerjaan. Akan tetapi, efektifitas struktur tersebut didukung dengan rendahnya kapasitas dalam menahan pengaruh beban gempa dan besarnya efek dari punching shear. Dalam penelitian ini, dua jenis sistem struktur akan dianalisa yang, yaitu pelat dengan balok dalok dan flat slab dengan drop panel. Studi kasus diambil pada bangunan empat lantai, perpustakaan IAIN Madura, dengan bentang panel $6 \mathrm{~m}$ dan $7.2 \mathrm{~m}$ yang masing-masing menggunakan dimensi drop panel $2 \mathrm{~m}$ dan $1.5 \mathrm{~m}$, akan dimodelkan ulang secara numerik menggunakan konsep rangka ekuivalen dan metode desain langsung menggunakan ETABS 2018. Pelat menggunakan balok juga dianalisa sebagai pembanding dan evaluasi. Tujuan yang diusulkan dari penelitian ini adalah untuk menilai kinerja flat slab dan drop panel agar mendapatkan efektivitas parameter bangunan yang sesuai standar.
\end{abstract}

Keywords: Flat slabs, balok, penebalan, drop panel, efektivitas

\section{Latar Belakang}

Sistem konstruksi flat slab adalah salah satu konsep dimana penggunaan elemen balok yang biasaya diaplikasikan pada konstruki konvensional dihilangkan. Konsep ini biasanya didukung dengan adanya penebalan di area kolom yang disebut sebagai drop panel yaitu pengganti balok pada konstruksi konvensional [1]. Konsep konstruksi dengan menghilangkan balok pada elemen struktur memberikan tampilan yang lebih baik khususnya di bagian arsitektural dan juga lebih memiliki tahanan kerentanan dalam kasus kebakaran dibandingkan dalam kasus biasa dimana elemen balok digunakan [2], [3]. Kondisi pasar konstruksi saat ini menunjukan bahwa pembangunan infrastruktur dituntut untuk dapat mengoptimalkan fungsi serta kapasitas yang terbatas dengan menitikberatkan pada pemanfaatan ruang yang luas dengan kapasitas maksimum serta estetika yang bebas [3]. Dari permasalahan tersebut, konsep flat slab dengan pemanfaatan drop panel menawarkan alternatif yang ekonomis dan sederhana dengan 
memanfaatkan ruang internal secara maksimal seperti bangunan-bangunan komersial pada umumnya yang menuntut keleluasaan, seperti hall, mall, theater, gedung olahraga dan struktur lainnya dimana ruang bebas tanpa elemen balok besar sangat menjadi perhatian [4], [5]. Namun, dengan tidak adanya elemen balok pada konstruksi yang menggunakan flat slab, kemampuan dalam menahan gaya geser secara signifikan berkurang. Distribusi gaya yang menginisiasi kerusakan secara horizontal akan mendukung fracture berlebih yang menyebabkan kegagalan struktur atau terjadinya punching shear effect [6]-[8]. Pertimbangan-pertimbangan desain seperti posisi dinding dan kolom atau optimasi sistem layout struktur serta kontrol deformasi harus sangat diperhatikan. Hal tersebut akan menentukan stabilitas struktur untuk menerima beban khususnya dengan tidak ada elemen balok untuk mendistribusikan beban [9].

Seperti yang disampaikan oleh Subramanian [10] dalam Tilva, dkk. [11], desain flat slab hanya dapat direalisasikan pada area dengan potensi gempa yang rendah dan dapat direncanakan dengan sistem tahanan beban baik secara vertical dan horizontal sesuai dengan ketentuan IS 1893 bagian I - 2002 [12]. Sedangkan untuk penerapan pada wilayah gempa tinggi, tidak diperkenankan penggunaan flat sla $b$ tanpa ada sistem penahan beban lateral. Sehingga berdasarkan hal tersebut, sistem penahan tambahan berupa drop panel harus ditambahkan untuk mendistribusikan beban secara baik pada elemen struktur kolom. Berdasarkan penelitian terdahulu, sistem bangunan tanpa menggunakan balok, rangka struktur utama didesain dengan kapasitas tahanan seismic minimum sebesar $25 \%$ dan $75 \%$ yang kemudian sisanya harus dialokasikan oleh dinding geser [4]. Penelitian tersebut didukung oleh penelitian lain terkait aplikasi penerapan sistem konstruksi dengan flat slab pada wilayah gempa rendah hingga sedang yang menyatakan harus ada konstribusi dukungan dinding geser pada elemen perkuatan struktur utamanya [4], [13]. Berdasarkan beberapa rujukan dari penelitian terdahulu, akan dilakukan evaluasi ulang bangunan menggunakan dua sistem yang berbeda menggunakan sistem pelat dan balok (umumnya dipakai) dan flat slab dengan drop panel (alternative sistem struktur denga ruang bebas). Studi kasus akan digunakan Gedung perpustakaan IAIN Madura yang mana bangunan tersebut akan dilakukan evaluasi ulang dengan perubahan fungsi bangunannya. Penggunaan sistem struktur flat slab dengan drop panel diharapkan dapat memberikan efektifivitas dari segi kinerja berbasis performa dengan konsentrasi pemanfaatan ruang dan maksimalisasi desain. Dari dua metode tersebut akan dilakukan evaluasi kapasitas dengan metode rangka ekuivalen dan metode desain langsung berdasarkan SNI 2847-2019 [14]. Rujukan pembebanan akan disesuaikan berdasarkan kategori risiko IV dengan faktor keutamaan gempa $I_{e} 1.50$ yang dikategorikan sebagai fasilitas penting yaitu fasilitas dan bangunan Gedung sekolah. Analisis respons situs diklasifikasikan sebagai tanah sedang (SD) dengan koefisien-koefisien situs dan parameter respons spectral gempa maksimum yang dipertimbangkan menyesuaikan kaidah berdasarkan SNI 1726-2019 [15].

\section{Studi Literatur}

Secara umum pada bangunan gedung, rangka struktur utama untuk menahan beban didukung oleh kolom, balok dan pelat. Namun, dalam penerapannya dimungkinkan melakukan konstruksi tanpa menerapkan balok, kasus tersebut dinamakan dengan penerapakan konsep struktur flat slab. Rangka struktur balok akan didistribusikan kepada pelat yang didukung oleh kolom sebagai penerapanannya sesuai ilustrasi pada Gambar 1(b). Konsep sejenis juga di ilustrasikan pada Gambar 1(c) dengan dukungan perbesaran dimensi ujung kolom yang disebut sebagai capital. Sedangkan Gambar 1(d) adalah penerapan sistem flat slab dengan dukungan drop panel untuk membantu proses distribusi beban seperti halnya pada Gambar 1(a) [16].

Flat slab atau flat plate juga dikategorikan sebagai medium-rise office dengan mengedepankan fungsi fasilitas serta meminimalisir rasio bentang dan tinggi antar lantai. Dengan tidak menggunakan balok, tinggi efektif setiap lantai menjadi relatif lebih tinggi selain itu dapat mengurangi berat sendiri struktur secara signifikan [17]. Dari segi pelaksanaan sistem struktur ini lebih sederhana jika dibandingkan dengan konstruksi konvensional menggunakan balok dikarenakan mengeliminir pekerjaan penulangan dan perancah untuk pekerjaan balok. Kemudian, didukung dengan implementasi atap langsung atau tanpa menggunakan plafon. Akan tetapi, dikarenakan tidak ada elemen struktur 
balok, sistem struktur flat slab sangat rentan dalam menahan gaya geser atau kekauan antara kolom dan pelat sangat rendah dengan tingkat punching shear relatif lebih tinggi dibandingkan konsep sistem struktur yang lain.

Punching shear adalah jenis kegagalan pelat yang diakibatkan oleh gaya lokal yang tinggi. Dalam sistem flat slab hal tersebut menjadi sangat umum khususnya diarea sekitar kolom. Kegagalan tersebut dapat terjadi tanpa ada indikasi kegagalan atau dikategorikan sebagai kegagalan geser secara langsung [18], [19]. Kasus punching shear juga dijelaskan pada studi sebelumnya oleh Kueres, dkk. yang mengkategorikan tahanan terbesar gaya external akan didukung sepenuhnya oleh kolom dibandingkan struktur flat slab [19]. Selain itu tingkat inclinasi kegagalan atau spalling beton pada tulangan lentur gabungan yang didukung oleh flat slab berada pada $25^{\circ}$ hingga $30^{\circ}$ yang mana lebih besar tingkat kegagalannya pada flat slab tanpa drop panel dengan integrity reinforcement pada sudut terbesar dapat dilihat pada Gambar 2. Kegagalan akibat inklinasi atau perubahan sudut juga dianalisa oleh peneliti lain, khususnya sebagai parameter utama dalam menentukan fracture mechanism vs kapasitas tegangan dan regangan [7], [20], [29], [21]-[28].

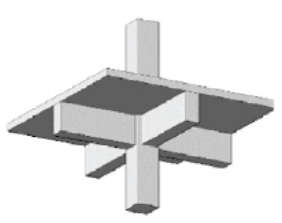

(a) Conventional

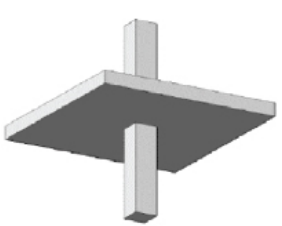

(b) Flat plate

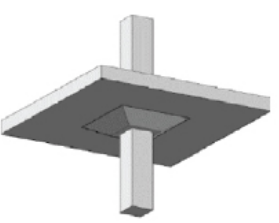

(c) Capital

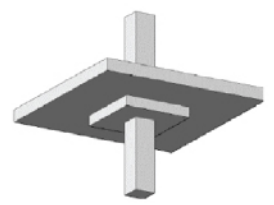

(d) Drop panel

Gambar 1. Sistem struktur rangka penahan beban [17]

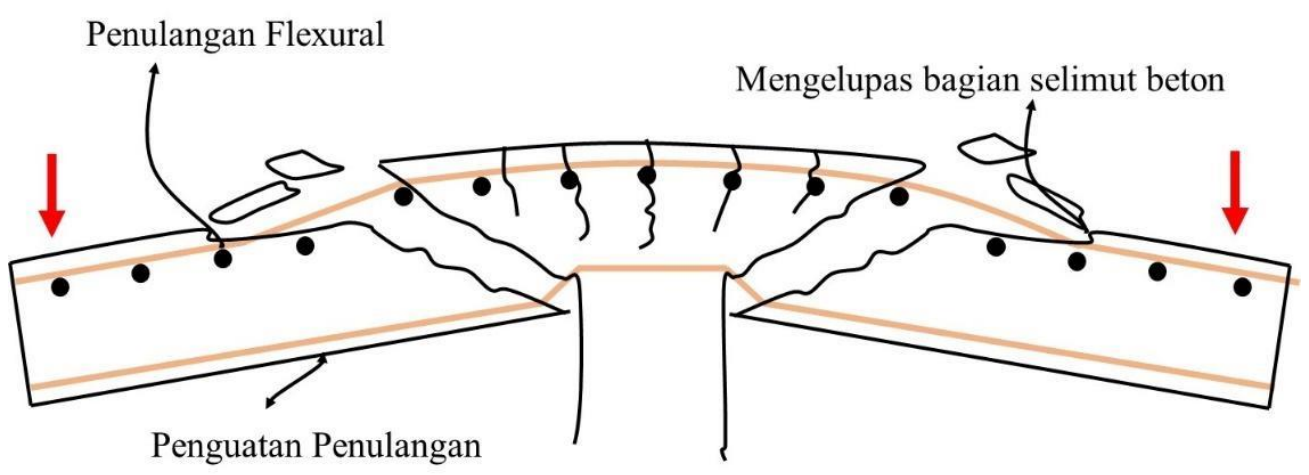

Gambar 2. Perilaku kegagalan post-punching flat slab [18]

Kasus lain terkait analisa implementasi material flat slab dengan dukungan balok serta pelat dua arah yaitu pada pembangunan coal yard PLTU Kalimantan Barat dibandingkan dengan konstruksi balok konventional merepresentasikan pemakaian material beton sebesar $2.1 \%$ dengan penulangan yang terpasang lebih banyak 9.67\%. Hal tersebut juga mempengaruhi berat struktur atau berat komponen yang ditahan oleh elemen kolom [30]. Selain hal tersebut, salah satu parameter tinjauan yang menjadi pertimbangan adalah pada waktu pengerjaan. Waktu pengerjaan untuk konstruksi flat slab relatif lebih cepat hingga mencapai $37 \%$ berbanding dengan pekerjaan pembalokan atau sistem struktur konvensional [31], [32]. Kemudian berdasarkan Tilva, dukungan flat slab akan menjadi lebih baik jika diposisikan dengan pemasangan drop panel. Pada konstruksi bangunan dengan flat slab dan bangunan flat slab dengan drop panel pada sistem struktur 4 lantai, tahanan gaya lateral bisa meningkat cukup besar dengan keruntuhan akibat punching shear antara $25^{\circ}$. Hal tersebut mengindikasi deformasi akan terjadi cukup besar atau bangunan cukup mampu menahan gaya lateral yang besar [11]. Studi lain terkait implementasi drop panel dengan merubah matrix dengan penambahan engineered cementitious composite (ECC). Penambahan ECC pada drop panel dapat memberikan dukungan secara maksimal dari segi dimensi dan kapasitas tahanan terhadap gempa [8][6], [21], [33], [34]. 


\subsection{Kapasitas Geser pada Flat Slab}

Kegagalan geser pada sistem struktur flat slab biasanya berbentuk kerucut terpancung seperti di ilustrasikan pada Gambar 1. Kegagalan tersebut normalnya terjadi karena punching shear atau akibat geser dua arah yang berfokus di kolom. Pertemuan pada joint kolom menyebabkan kegagalan diawali oleh kelelehan tulangan diarea penulangan sebelum kolom. Sehingga sistem strong column weak beam masih dapat tercapai. Dalam hal ini flat slab yang akan mengalami perlemahan kemudian kolom. Berdasarkan ACI 318-1983 [35], Panjang minimum dan penyaluran tulangan harus memenuhi batasan sesuai Tabel 1 yang dipasang untuk pelat dengan proporsi normal dan mampu menahan beban gravitasi. Selanjutnya untuk kapasitas desain berdasarkan SNI 2847-2019 [36] , tahanan pelat dua arah terhadap punching shear adalah diambil dari nilai (a), (b) dan (c) yang paling kecil, sesuai Tabel 2.

Tabel 1. Panjang penyaluran yang disyaratkan untuk penulangan ulir pada pelat dua arah tanpa balok [36]

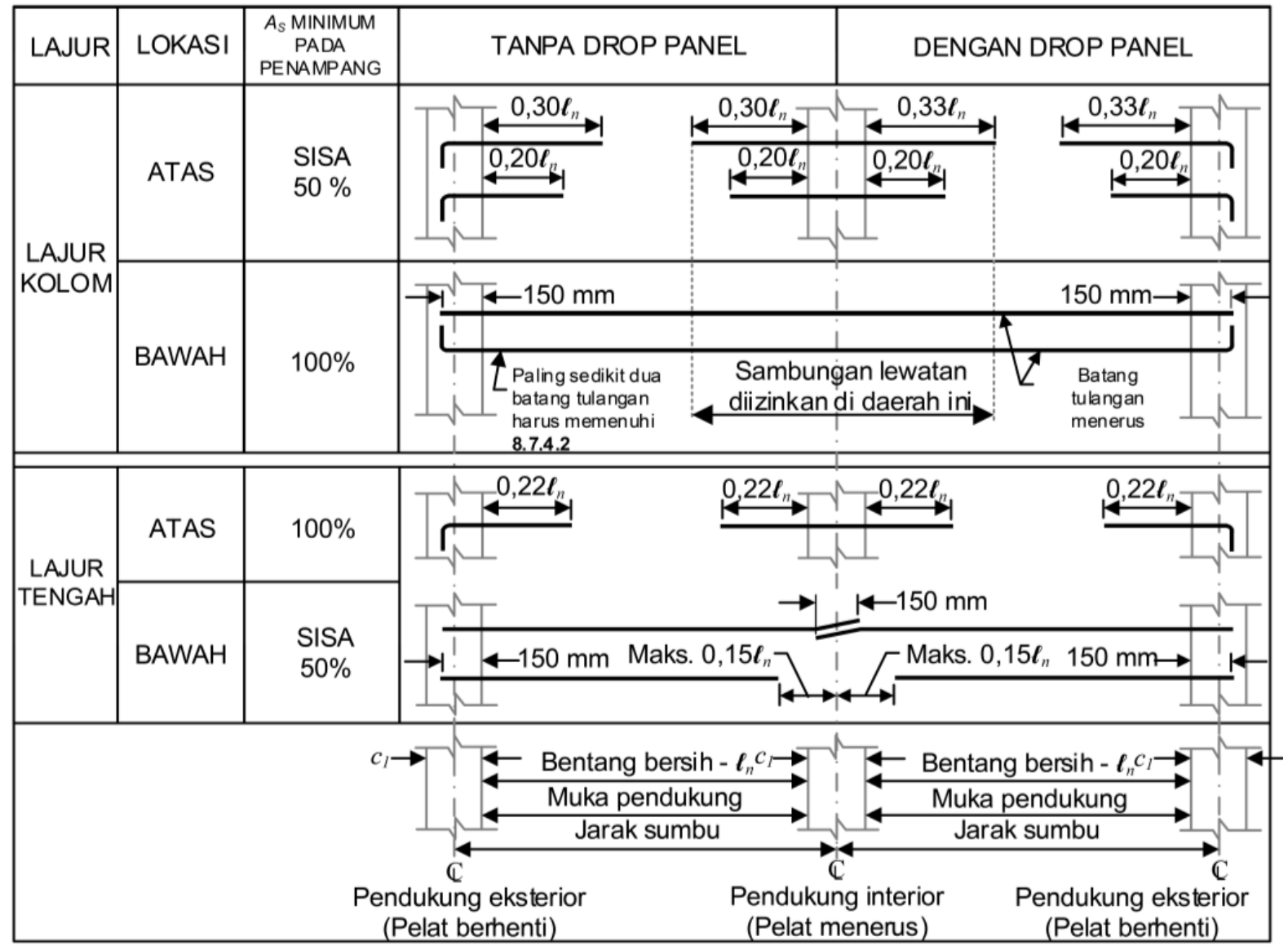


Tabel 2. Persyaratan kekuatan geser nominal [36]

\begin{tabular}{|c|c|c|c|}
\hline $\begin{array}{l}\text { Aksi } \\
\text { geser }\end{array}$ & \multicolumn{2}{|c|}{ Kekuatan geser nominal $V_{n}$} & \\
\hline $\begin{array}{l}\text { Satu } \\
\text { arah }\end{array}$ & \multicolumn{2}{|r|}{$\left.0,11 \lambda \sqrt{f_{c}} b_{w} h\right)$} & (a) \\
\hline \multirow{2}{*}{$\begin{array}{l}\text { Dua } \\
\text { arah }\end{array}$} & \multirow{2}{*}{$\begin{array}{c}\text { Terkecil } \\
\text { dari: }\end{array}$} & $\left(1+\frac{2}{\beta}\right)\left(0,11 \lambda \sqrt{f_{c^{\prime}} b_{o}} h\right)^{[1]}$ & (b) \\
\hline & & $2\left(0,11 \lambda \sqrt{f_{c}^{\prime}} b_{o} h\right)$ & (c) \\
\hline
\end{tabular}

\section{Metode Penelitian}

Dalam penelitian ini akan dilakukan evaluasi kapasitas dari dua sistem struktur yaitu flate slab dan flat slab dengan drop panel sesuai dengan data bangunan Gedung Perpustakaann IAIN Madura pada Tabel 3. Spesifikasi bangunan akan dimodelkan tipikal menggunakan Software Analisa numerik ETABS 2018. Tinggi bangunan total adalah $15.8 \mathrm{~m}$ dengan bentuk bangunan regular seperti pada Gambar 3(a). Illustrasi tampak bangunan 3 dimensi sesuai Gambar 3(b) dengan modifikasi perencanaan menggunakan flat slab dengan balok (Gambar 4(a)) dan flat slab dengan drop panel (Gambar 4(b)).

Pembenanan sesuai dengan fungsi bangunan kategori risiko IV. Dengan detail kategori desain seismik A-C yang dievaluasi dengan auto lateral load berdasarkan ETABS 2018. Kombinasi pembebanan yang diinputkan selain beban gempa adalah 1.4 beban mati dan 1.2 beban mati dan 1.6 beban hidup. Kemudian berat sendiri struktur juga dievaluasi secara langsung. Variasi Analisa yang dilakukan dibagi menjadi dua kategori berdasarkan jenis sistem struktur yang dipakai yaitu flat slab dengan balok dan flat slab dengan drop panel. Kedua kategori yang dipakai memakai variasi Panjang bentang yang sama dengan dua variasi bentang, yaitu dengan Panjang bentang $7.2 \mathrm{~m}$ dan $6.0 \mathrm{~m}$. Untuk kageori pertama, flat slab dengan balok, dipasangkan berurutan sesuai Panjang bentang menggunakan dimensi balok $30 \times 70 \mathrm{~cm}$ dan $30 \times 60 \mathrm{~cm}$. Sedangkan kategori kedua, flat slab dengan drop panel, dikondisikan secara berturut-turut dengan drop panel $2.0 \mathrm{~m}$ dan $1.5 \mathrm{~m}$. Tebal drop panel untuk kedua kategori di inputkan sama yaitu dengan tebal $250 \mathrm{~mm}$. Selain itu untuk pemodelan flat slab dengan.

Tabel 3. Data primer pemodelan struktur flat slab

\begin{tabular}{l|l}
\hline \multicolumn{2}{c}{ Data elemen struktur Gedung IAIN Madura } \\
\hline$f^{\prime} c$ dan $f y$ & 35 Mpa dan 400 MPa \\
Diameter tulangan terpasang & D19 kolom, D16 Balok \\
Jumlah lantai & 4 lantai \\
Tinggi tiap lantai berurutan & $4400 \mathrm{~cm} .4000 \mathrm{~cm} *$ dan $3000 \mathrm{~cm}$ \\
Tebal pelat lantai dan atap & $12 \mathrm{~cm}$ \\
Kolom & $50 \mathrm{~cm} \mathrm{x} 50 \mathrm{~cm}$ \\
Balok tipe 1 $(\mathrm{L}=7,2 \mathrm{~m})$ & $30 \mathrm{~cm} \mathrm{x} \mathrm{70} \mathrm{cm}$ \\
Balok tipe 2 $(\mathrm{L}=6,0 \mathrm{~m})$ & $30 \mathrm{~cm} \times 60 \mathrm{~cm}$ \\
Drop panel tipe 1 $(\mathrm{L}=7,2 \mathrm{~m})$ & $2000 \mathrm{~cm}$ \\
Drop panel tipe 2 $(\mathrm{L}=6,0 \mathrm{~m})$ & $1500 \mathrm{~cm}$ \\
\hline * tinggi lantai dua dan tiga sama
\end{tabular}

\footnotetext{
* tinggi lantai dua dan tiga sama
} 
Type 1 : Balok $30 \times 70 \mathrm{~cm}$ Type 2 : Balok $30 \times 60 \mathrm{~cm}$

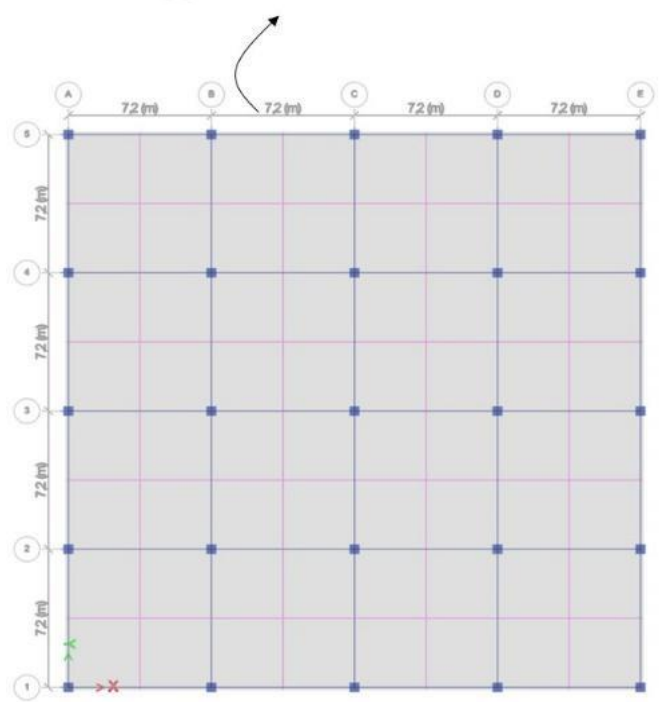

(a)
Type 1 : Drop panel $200 \mathrm{~cm}$ x $200 \mathrm{~cm} \times 25 \mathrm{~cm}$ Type 1: Drop panel $150 \mathrm{~cm} \times 200 \mathrm{~cm} \times 25 \mathrm{~cm}$

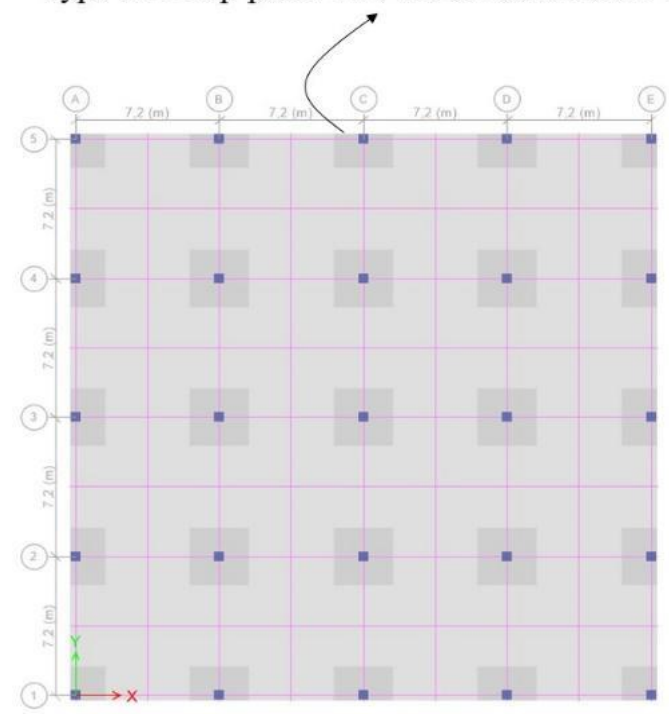

(b)

Gambar 3. Denah pemodelan struktur; (a) Pelat dengan balok, (b) Flat slab dengan drop panel 
Axial Force and Biaxial Moment Design For $\mathrm{P}_{\mathrm{u}}, \mathrm{M}_{\mathrm{u} 2}, \mathrm{M}_{\mathrm{u} 3}$

\begin{tabular}{c|c|c|c|c|c|c}
\hline $\begin{array}{c}\text { Design } \mathbf{P}_{\mathrm{u}} \\
\mathbf{k N}\end{array}$ & $\begin{array}{c}\text { Design } \mathbf{M}_{\mathrm{u} 2} \\
\mathbf{k N}-\mathbf{m}\end{array}$ & $\begin{array}{c}\text { Design } \mathbf{M}_{\mathrm{u} 3} \\
\mathbf{k N}-\mathbf{m}\end{array}$ & $\begin{array}{c}\text { Minimum } \mathbf{M}_{2} \\
\mathbf{k N}-\mathbf{m}\end{array}$ & $\begin{array}{c}\text { Minimum } \mathbf{M}_{3} \\
\mathbf{k N}-\mathbf{m}\end{array}$ & $\begin{array}{c}\text { Rebar \% } \\
\%\end{array}$ & $\begin{array}{c}\text { Capacity Ratio } \\
\text { Unitless }\end{array}$ \\
\hline 202,9385 & 110,0859 & $-110,0859$ & 6,1369 & 6,1369 & 1,51 & 0,464 \\
\hline
\end{tabular}

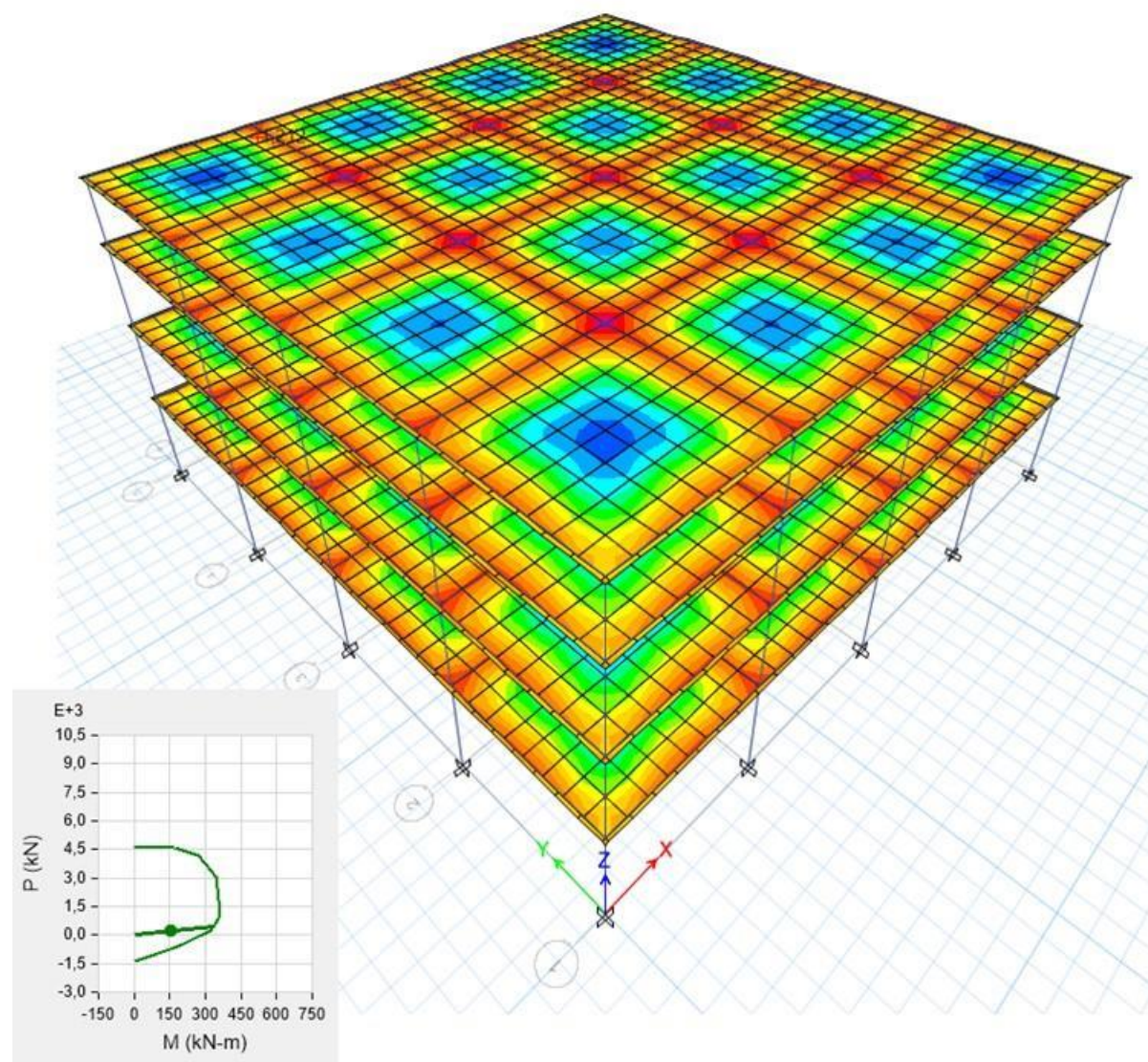

(a)
Axial Force and Biaxial Moment Design For $P_{4}, M_{v 2}, M_{43}$

\begin{tabular}{c|c|c|c|c|c|c}
\hline $\begin{array}{c}\text { Design } \mathbf{P}_{\mathrm{u}} \\
\mathrm{kN}\end{array}$ & $\begin{array}{c}\text { Design } \mathbf{M}_{\mathrm{v} 2} \\
\mathrm{kN}-\mathrm{m}\end{array}$ & $\begin{array}{c}\text { Design } \mathbf{M}_{\mathrm{u} 3} \\
\mathbf{k N}-\mathrm{m}\end{array}$ & $\begin{array}{c}\text { Minimum } \mathbf{M}_{2} \\
\mathbf{k N}-\mathbf{m}\end{array}$ & $\begin{array}{c}\text { Minimum } \mathbf{M}_{3} \\
\mathbf{k N}-\mathbf{m}\end{array}$ & $\begin{array}{c}\text { Rebar \% } \\
\%\end{array}$ & $\begin{array}{c}\text { Capacity Ratio } \\
\text { Unitless }\end{array}$ \\
\hline 137,3824 & $-171,3857$ & 171,1694 & 4,1544 & 4.1544 & 1,51 & 0.759 \\
\hline
\end{tabular}

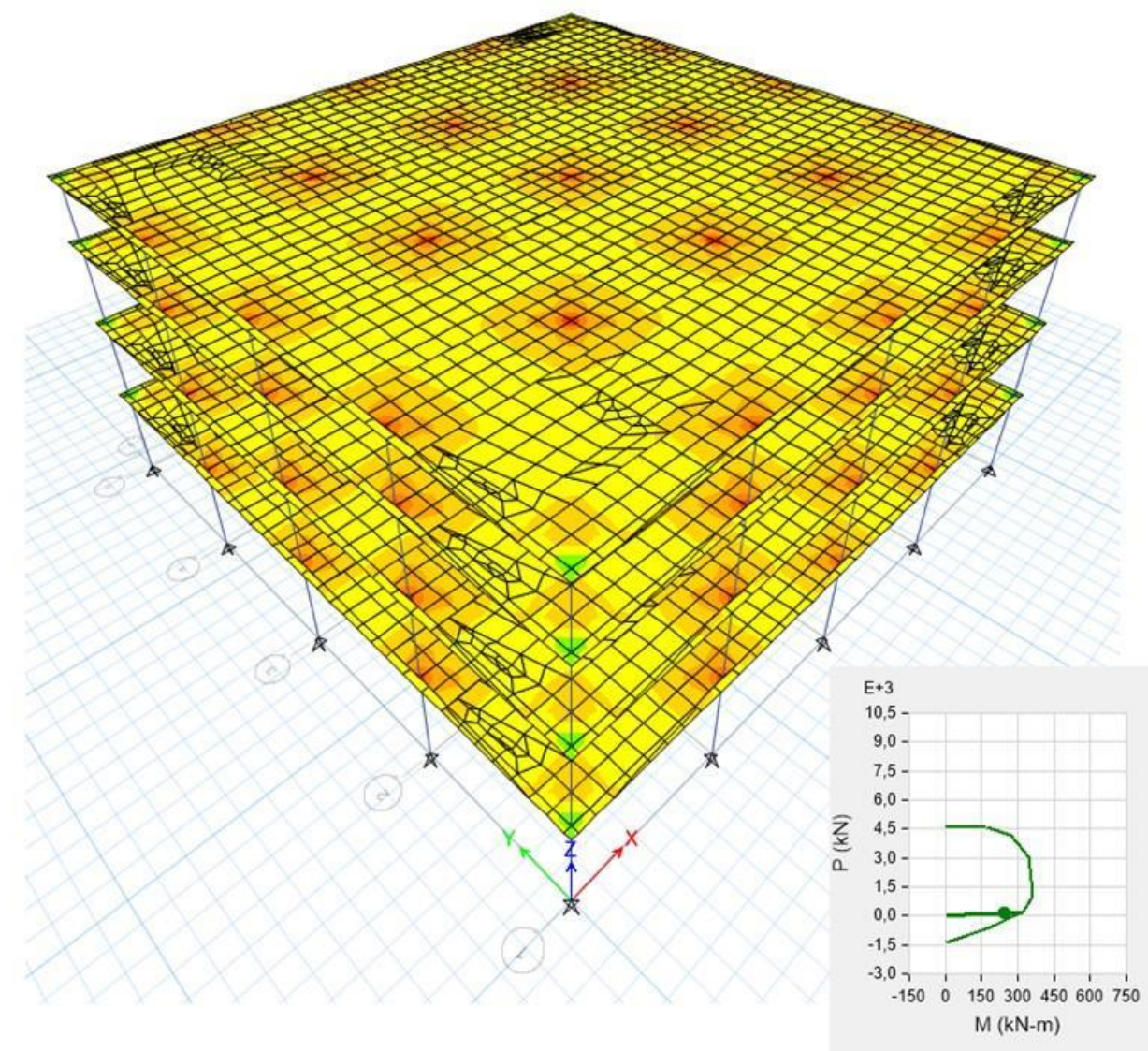

(b)

Gambar 4. Denah pemodelan struktur; (a) Pelat dengan balok, (b) Flat slab dengan drop panel 


\section{Prospective Result - Preliminary Analysis}

Berdasarkan pemodelan awal (lihat Gambar 4) dari dua kategori model dengan 2 parameter bentang maka dapat diilustarsikan terkait kapasitas berbanding dengan perilaku depormasi struktur vs berat bangunan total. Sesuai Gambar 4(a) kapasitas kritis (gradasi merah) struktur didominasi pada area balok. Semua beban terpikul sepanjang bentang yang kemudian didistribusikan ke elemen struktur balok, sehingga kekakuan utama struktur utama berada pada balok. Distribusi beban dengan deformasi dapat dilihat pada Tabel 4. Struktur $K 1$ memberikan deformasi arah $x, y$ dan $z$ dengan nilai relatif lebih kecil jika dibandingkan dengan struktur $K 2$. Hal tersebut di indikasi karena balok memberikan integritas struktur dengan baik, dapat dilihat pada kapasitas rasio sesuai Gambar 4(a,b), yang mana memiliki nilai 0.464 jika dibandingkan dengan $K 2$ yang mencapai 0.759 . Akan tetapi jika dibandingkan dengan berat struktur $K 1$ merepresentasikan berat lebih besar $10 \%$ daripada struktur $K 2$. Hal ini akan mempengaruhi apabila kategori desain seismic sudah dimasukan kedalam Analisa. Preliminary analysis ini hanya meninjau akibat dua kombinasi beban mati dan beban hidup dengan mengabaikan beban gempa.

Tabel 4. Deformasi maksimum pada struktur

\begin{tabular}{lccccc}
\hline \multicolumn{1}{c}{ Kategori } & $\begin{array}{c}\text { Deformasi } \\
\text { arah } U x \\
{[\mathrm{~mm}]}\end{array}$ & $\begin{array}{c}\text { Deformasi } \\
\text { arah } U y \\
{[\mathrm{~mm}]}\end{array}$ & $\begin{array}{c}\text { Deformasi } \\
\text { arah } U z \\
{[\mathrm{~mm}]}\end{array}$ & $\begin{array}{c}\text { Berat total } \\
\text { Bangunan } \\
{[\text { Ton] }}\end{array}$ & Ket. \\
K1 - Pelat dengan balok & 0.037 & 0.033 & 2.252 & 174.76 & safe \\
K2 - Flat slab dengan drop panel & 0.055 & 0.01 & 5.393 & 128.12 & safe \\
\hline
\end{tabular}

Sehingga berdasarkan data tegangan, rasio kapasitas, deformasi yang dibandingkan dengan berat struktur, kategori struktur $K 2$ menawarkan alternatif dengan kaidah pemanfaatan yang baik yang masih masuk kedalam kaidah kapasitas berbasis kinerja.

\section{Kesimpulan}

Preliminary analysis yang dilakukan diharapkan dapat memberikan informasi awal sebagai pertimbangan tahapan desain untuk kajian lebih lanjut terkait implementasi flat slab dengan drop panel. Efektifitas dan kapasitas sistem struktur tersebut akan dievaluasi dengan perbandingan performance level pada tahapan selanjutnya dengan tetap memperhatikan kegagalan akibat punching shear. Berdasarkan kajian awal dapat diambil beberapa kesimpulan antara lain:

a. Proporsi tegangan pada struktur pelat dengan balok dapat mencapai tegangan kritis dan hanya terkonsentrasi pada area balok, yang mana pada strukur flat slab dengan drop panel, tegangan lebih terdistribusi secara merata.

b. Distribusi rasio struktur pelat dengan balok terimplementasi lebih kecil dengan rasio 0.464 berbanding 0.759 dengan struktur flat slab dengan drop panel.

c. Berat sistem struktur flat slab dengan drop panel lebih ringan $10 \%$ jika dibandingkan dengan sistem struktur pelat dengan balok.

Untuk Analisa selanjutnya akan befokus pada perilaku sistem struktur flat slab dengan drop panel khususnya untuk implementasi pada kategori desain seismik berdasarkan rujukan SNI 1726-2019.

\section{Referensi}

[1] B. Kumar, "Use of Flat Slabs in Multi-Storey Commercial Building," Int. J. Recent Trends Eng. Res., vol. 3, no. 9, pp. 24-36, 2017, doi: 10.23883/ijrter.2017.3426.2cvxu.

[2] A. R. Asy-syifa and J. Tarigan, "Analisa Flat Slab Dengan Memakai Drop Panel Kolom Persegi Dengan Variasi Pembebanan Life Load," J. Tek. Sipil USU, vol. 6, no. 1, pp. 1-11, 2017.

[3] F. Sutanto, E. Samsurizal, and G. S. Budi, "Analisa Perhitungan Struktur Bangunan Gedung Head Office dan Showroom Yamaha Pontianak," J. Tek. Sipil Univ. Tanjungpura, vol. 3, no. 2, pp. 1-9, 2014. 
[4] W. Hardianto, A. B. Hanintyo, H. Indarto, and I. Nurhuda, "Perencanaan Struktur Gedung Kuliah di Yogyakart," J. Karya Tek. Sipil, vol. 3, no. 1, pp. 1056-1068, 2014.

[5] D. R. Teruna and S. Prawira, "Studi Perbandingan Penggunaan Flat plate dan Flat slab dengan drop panel pada struktur Bangunan ditinjau dari Segi Volume," J. Tek. Sipil USU, vol. 1, no. 1, pp. 1-8, 2016.

[6] A. Tambusay, P. Suprobo, Faimun, and A. A. Amiruddin, "Analyses Behavior of Slab-Column Connections Using ECC Material Based," Easec, vol. 14, no. January, 2016, doi: 10.13140/RG.2.1.1517.7367.

[7] I. Komara, A. Tambusay, W. Sutrisno, and P. Suprobo, "Engineered Cementitious Composite as an innovative durable material: A review," ARPN J. Eng. Appl. Sci., vol. 14, no. 4, pp. 822-833, 2019.

[8] A. Tambusay, P. Suprobo, and Faimun, "Studi Eksperimental Perilaku Hubungan Pelat-Kolom Menggunakan Drop Panel dengan Serat PVA-ECC Terhadap Beban Siklik Lateral," in Konferensi Nasional Pascasarjana Teknik Sipil (KNPTS), 2014, no. November, pp. 1-8.

[9] H. A. Syarif and Z. Djauhari, "Respon Struktur Sistem Flat Slab-Drop Panel Pada Gedung Bertingkat Tak Beraturan Terhadap Beban Gempa dengan Analisis Respon Spektrum,” Apl. Teknol., vol. 11, no. 2, pp. 97-104, 2019.

[10] N. Subramanian, "Evaluation and enhancing the punching shear resistance of flat slabs using HSC," Indian Concr. J., vol. 79, no. 4, pp. 31-37, 2005.

[11] V. k Tilva, B. . Vyas, and P. Thaker, "Cost Comparison Between Flat Slabs with Drop and without Drop in Four Storey Lateral Load Resisting Building," J. Natl. Conf. Recent Trends Eng. Technol., vol. 1, no. May, pp. 1-5, 2011.

[12] T. Boikova, D. Solovyov, and V. Solovyova, "Concrete for Road Pavements," Procedia Eng., vol. 189, no. May, pp. 800-804, 2017, doi: 10.1016/j.proeng.2017.05.124.

[13] M. Nurhadi, A. S. Budi, and Supardi, "Evaluasi Kinerja Gaya Gempa Pada Struktur Gedung Bertingkat Dengan Anaisis Pushover Berdasar Pada Drift dan Displacement Menggunakan Software ETABS (Studi Kasus: Hotel di Wilayah Karanganyar)," Matriks Tek. Sipil, vol. 2, no. 2, pp. 123-130, 2014.

[14] Badan Standardisasi Indonesia, "Persyaratan beton struktural untuk bangunan gedung dan penjelasan (ACI 318M-14 dan ACI 318RM-14, MOD)," 2019.

[15] Badan Standardisasi Indonesia, "Tata cara perencanaan ketahanan gempa untuk struktur bangunan gedung dan nongedung SNI 1726:2019," 2019.

[16] A. H. W. Pratomo, "Studi Efisiensi Penggunaan Flat Slab dengan Drop Panel terhadap Pelat Konvesional Pada Gedung 5 Lantai," Kurva S, vol. 53, no. 9, pp. 1-7, 2018, doi: 10.1017/CBO9781107415324.004.

[17] S. A. Aman, M. A. Khaliq, M. J. Uddin, S. Imranuddin, and S. S. Rizwanuddin, Syed Khaza; Pasha, “Analysis And Design of A Multi Storey Building with Flat Slab ( C + G + 9 ) Using ETABS," Int. J. Innov. Technol., vol. 6, no. 01, pp. 176-183, 2018.

[18] A. Torabian, B. Isufi, D. Mostofinejad, and A. P. Ramos, "Behavior of thin lightly reinforced flat slabs under concentric loading," Eng. Struct., vol. 196, no. June, pp. 1-16, 2019, doi: 10.1016/j.engstruct.2019.109327.

[19] D. Kueres, C. Siburg, M. Herbrand, M. Classen, and J. Hegger, "Uniform Design Method for punching shear in flat slabs and column bases," Eng. Struct., vol. 136, pp. 149-164, 2017, doi: 10.1016/j.engstruct.2016.12.064.

[20] E. Wahyuni, B. Suswanto, and I. Komara, "Effects of Angle of Inclination Cables on The Performance of Submerged Floating Tunnel Under Hydrodynamic Load," in The 5th Environmental Technology and Management Conference "Green Technology towards Sustainable Environment, 2015, no. 5, pp. 15-26.

[21] I. Komara, A. Tambusay, W. Sutrisno, P. Suprobo, and D. Iranata, "The Investigation study of improving Durability Performance of Marine Infrastructure by using the Engineered Cementitious Composite," in The 14th International Student Conference on Advanced Science and Technology (ICAST) 2019, 2019, pp. 8-12, doi: 10.4324/9780367853815-2.

[22] I. Komara, E. Wahyuni, P. Suprobo, and K. Taşkin, "Micro-Structural Characterization of the bond strength capacity of adhesive material in the alternative of cold-formed steel frame system," IOP Conf. Ser. Mater. Sci. Eng., vol. 462, no. 1, 2019, doi: 10.1088/1757-899X/462/1/012004.

[23] W. A. Santoso, B. Suswanto, E. Wahyuni, and I. Komara, "The experimental study of the effect of screw and adhesive connection in the variation of cold-formed roof truss framing system," IPTEK J. Proc. Ser., vol. 0, no. 6, pp. 39-44, 2019, doi: 10.12962/j23546026.y2018i6.4874.

[24] I. Komara, E. Wahyuni, P. Suprobo, and K. Taskin, "Assessing the tensile capacity of cold-formed steel connections using self-drilling screws and adhesive materials," Int. J. Adv. Sci. Eng. Inf. Technol., vol. 8, no. 2, 2018, doi: 10.18517/ijaseit.8.2.4314.

[25] I. Komara, K. Taşkin, E. Wahyuni, and P. Suprobo, "Adhesively Bonded Connection and Screw Connection of Single Truss Cold-Formed Steel Canals Frames Due to Tensile Test Behavior," in 
International Conference on Civil and Environmental Engineering, 2017, pp. 1-10.

[26] I. Komara, K. Taşkin, E. Wahyuni, and P. Suprobo, "Experiment on Cold-Formed Steel C-Section Joint With Screw ond Adhesive Material," MATTER Int. J. Sci. Technol., vol. 3, no. 2, pp. 51-63, 2017, doi: https://dx.doi.org/10.20319/mijst.2017.32.5163 EXPERIMENT.

[27] I. Komara, E. Wahyuni, P. Suprobo, and K. Taskin, "Experimental Study of Adhesively Bonded Connection Strength in Cold-Formed Steel Roof Truss Connection," in Regional Conference in Civil Engineering (RCCE) The Third International Conference on Civil Engineering Research (ICCER), 2017, pp. 1-4.

[28] I. Komara, E. Wahyuni, and P. Suprobo, "A study on Cold-formed Steel Frame Connection : A review," IPTEK, J. Technol. Sci., vol. 28, no. 3, pp. 83-89, 2017.

[29] I. Komara, E. Wahyuni, and P. Suprobo, "Studi Numerik Perilaku Sambungan Baut dan Adhesive Pada Struktur Rangka Atap Baja Ringan," in Konferensi Nasional Pascasarjana Teknik Sipil (KNPTS), 2016, pp. 1-9.

[30] M. I. Syamsi, "Perbandingan Analisis Two Way Slab With Beam dengan Flat Slab ( Studi Kasus : Coal Yard PLTU Kalimantan Barat )," vol. 18, no. 2, pp. 168-175, 2015.

[31] A. C. Purnama, "Modifikasi Perencanaan Gedung Amaris Hotel Madiun Dengan Menggunakan Metode Flat Slab dan Shear wall,” Institut Teknologi Sepuluh Nopember, 2017.

[32] P. Rahmasari, Y. Letyowati, and G. S. Budi, "Analisisi Perhitungan Struktur Gedung Pendidikan Fakultas MIPA Universitas Tanjungpura Pontianak,” J. Tek. Sipil USU, vol. 1, no. 1, pp. 1-9, 2013.

[33] B. Suryanto, A. Tambusay, and P. Suprobo, "Crack Mapping on Shear-critical Reinforced Concrete Beams using an Open Source Digital Image Correlation Software Crack Mapping on Shear-critical Reinforced Concrete Beams using an Open Source Digital Image Correlation Software,” no. September, 2017, doi: 10.9744/ced.19.2.93-98.

[34] A. Tambusay, P. Suprobo, A. Faimun, and A. A. Amiruddin, "Finite element modellingofa reinforced concrete slab-column connection under cyclic lateral load," Int. J. Appl. Eng. Res., vol. 12, no. 9, pp. 19871993, 2017.

[35] A. C. I. Committee, Building Code Requirements for Structural Concrete ( ACI 318-11 ). .

[36] Badan Standardisasi Indonesia, "Beban minimum untuk perancangan bangunan gedung dan struktur lain," 2013. 